\title{
L2 English as a Backup for L3 Czech
}

\author{
Linda Doleží
}

\begin{abstract}
In my article I would like to discuss the role of English as a "backup" language as a result of language attrition phenomena. Usually, dominant language interference is described in connection to mother tongue attrition and is considered as one of its natural but negative outcomes. Less attention is paid to language attrition and interaction among second or foreign languages. First, I would like to describe language attrition, its main features and characteristics and factors that influence it and I would like to challenge the "use it or lose it" rule (Schmid, 2019). Attention will be paid to mother tongue attrition (Schmid, 2011) and second/foreign language attrition (Schmid and Mehotcheva, 2012). Furthermore, I would like to understand how L2 English interacts with L3 Czech in L1 Arabic speaker who has a scarce access to possibilities of using his second language - Czech. Examples of different language attrition and language contact or interaction phenomena (for example "To je unofficial čtvrt' budovaný against the law" etc.) will be depicted based on naturalistic, recorded data of a speaker who has acquired typologically interesting and very "different" languages. Interference and codeswitching of the languages involved will be discussed and compared to data already available in various linguistic contexts (i.e. Dewaele, 1998 and Selinker, Baumgartner-Cohen, 1995 in Murphy, 2003). Last but not least, the importance of holistic approach to multilingual mind and its importance for language learning, preservation, teaching and testing will be pointed out. Yates and Terraschke (2013) refer to the uniqueness of the situation, to the role of emotions connected to the language itself and to the role of the language in the family and the community when speaking about keeping our mother tongues. In this case study I would like to show that there should always and generally - not only in the case of using and keeping mother tongues - be a space for individual and highly variable approach to language learners and users and their linguistic trajectories (Pavlenko, 2005).
\end{abstract}

Key words: language attrition, language interaction, code switching, emotions, language teaching

\section{Introduction}

When guiding our students on the way of learning a new language, our aim is to help them not only to learn the language but also to keep it. It is amazing to observe that some students learn quickly, easily and their process of learning a new language is accompanied by lightness, while on the other hand for some students the very same aim is unreachable. Some students forget newly gained knowledge as soon as the semester or course finishes, other keep their knowledge and even extend it. Many students are surprised that when learning a new foreign language, the previously learned foreign language starts to be active too and interferes with the new one. Dealing with multilingual mind is never easy. Languages are acquired, used, lost, refreshed, reused, lost, forgotten. There are many scenarios as to what can happen to our languages. Our mother tongue seems to be 
the most resistant as to changes and attrition, nevertheless, it is not always the case and various reasons can lead to deterioration of our mother tongue competences or to its complete loss (see for example Schmid, 2011 or more recent Oxford Handbook of Language Attrition, 2019). As to second or foreign language attrition according to Schmid and Mehotcheva (2012) empirical studies on foreign or second language loss remain limited. There are also more factors at play during the process of their acquisition and the individual linguistic trajectories, as Pavlenko (2005) puts it, may differ a lot. In this paper examples of possible language contact between Czech as a second (chronologically third) language and English as a second language will be shown. Interference at various levels will be discussed and examples of code-switching will be presented. Nevertheless, in many cases there is a very thin line between these phenomena. The question is whether the examples relate to language contact phenomena or rather serve as language attrition evidence.

\section{Languages in Contact}

Multilingual mind is magical in its unpredictable behaviour. Languages do not live there separately but in a constant, dynamic interplay - sometimes positive and conscious, sometimes negative and out of control, leading to mistakes. Whenever one language is activated, all of the languages get a certain amount of activation too. Interference often occurs when languages influence each other (Nebeská, 2017). Multilinguals sharing one or more of their languages can afford to codeswitch and create a unique way of putting their messages across. Code-switching is the presence of lexical or sentential material belonging to different linguistic systems, provided that its different origin is still transparent in the speaker's output. Borrowing is morphophonologically integrated in the recipient language, code-switching is typically not. While lexical borrowings can be used by monolinguals, code-switching is always the production of (at least partial) bi- and multilinguals (Manfredi et al., 2015, p. 286, similarly Nekula, 2013).

Examples of various types of code-switching ${ }^{1}$ :

(1) Tag-switching

It's a nice day, hana? (hai nā isn't)

(Panjabi)

(2) Intra-sentential switching

Won o arrest a single person (won o they did not)

(Yoruba)

\footnotetext{
${ }^{1}$ CODE-MIXING AND CODE-SWITCHING. Concise Oxford Companion to the English Language. Retrieved July 31, 2018 from Encyclopedia.com: http://www.encyclopedia.com/humanities/encyclopediasalmanacs-transcripts-and-maps/code-mixing-and-code-switching
}

$16 \quad$ Studie/Study 
(3) Intersentential switching

Sometimes I'll start a sentence in English y termino en español (and finish it in Spanish)

(Spanish)

(4) Intra-word switching

shoppã

(English shop with the Panjabi plural ending)

kuenjoy

(English enjoy with the Swahili prefix "ku", meaning "to").

The above-mentioned phenomena can happen not only between a mother tongue and another language but also between second and third languages, see the examples below (Murphy, 2003, p. 1):

a) Dutch (L1), English (L2), French (L3):

Ils veulent gagner more, euh, plus. (Dewaele, 1998)

b) English (L1), French (L2), German (L3):

Tu as mein Fax bekommen. (Selinker, Baumgartner-Cohen, 1995)

Even though other options are possible (for example Pavlenko's 2004 five types of cross-linguistic influence) in this paper I will analyse the data in terms of four types of code-switching described above and as defined and clarified by MyersScotton (1992). Similarly to Manfredi et al. (2015), the author also contrasts the code-switches with borrowings. Borrowing has become part of the matrix language mental lexicon, while code-switched forms remain embedded language material which only occurs in matrix language morphosyntactic frames during codeswitching discourse (p. 21).

\section{Case study}

\subsection{Subject}

I collected naturalistic data via audio-recording from a subject (man, age 67) whose mother tongue is Arabic (L1), second language English (L2) - learned in usual instructional context and used intensively in the work environment, and last but not least second/foreign language Czech (L3) - learned through instructional context at first, used during university studies and personal or family life when getting married to a native speaker of Czech. Schmid and Mehotcheva (2012, p. 3). clearly distinguish between foreign and second languages through the instructional context. Second language refers according to these authors to naturalistically acquired language while foreign language deals with a school/university language. It is difficult to determine the level of Czech as a foreign/second language 
before the onset of attrition and generally it is difficult to determine ultimate attainment (Schmid, Mehotcheva, 2012, p. 17). Nevertheless, through self-evaluation of the subject we can deduce that it could be somewhere between B2 and C1. Before the research started the subject had had a very rare contact with Czech for more than 30 years. I would like to describe some language contact phenomena first and then discuss what may be the reasons for keeping the language alive as opposed to forgetting it.

\subsection{Data}

The aim of my study was to observe possible language attrition effects in Czech as the second (chronologically speaking, third language) and the role of English - the only common language the participants of the conversations had next to Czech. Data were recorded during natural conversations in various situations with the help of telephone. Data were transcribed and qualitatively analysed. In this paper I am focusing mainly on the linguistic part of the data, rather than the conversational issues (as in for example Auer, 2002), that is why I illustrate the language contact phenomena within examples extracted from the conversations. I am aware that for a deeper understanding of language contact phenomena in general the data would deserve much more attention from a broader perspective. In our data analyses I will strongly rely on Schmid (2011) even though the author focuses on bilingual speakers' attrition and thus pays attention to bilingual lexicon which is affected by the loss of L1 - mother tongue due to growing force of second language - L2. I suppose that similar phenomena can be related to multilingual lexicons and minds. While cross-linguistic influence may be caused by the closeness of two language systems, language attrition is related to decay or loss in one of the systems (p.38). When applying this to the lexicon, the words from one language become for various reasons simply inaccessible. Thus, when a speaker wants to retrieve a word from the memory, similar items from other languages will activate and the optimal choice will be made. The examples have been divided into two groups - data showing the role of English in the examples of interference and subgroups of data showing how English and Czech interact. Translations are included in the brackets, the target-like structures (where possible) are in italics. English elements are highlighted in bold.

\subsubsection{Less visible elements - interference from English}

Example (a) shows a violation of word-order rules because the demonstrative pronoun "to" needs to occupy a different position in the sentence. Word-order pattern was most probably transferred from English to Czech. However, Arabic follows the same word order and that is why I am not able to determine where this particular influence comes from. Example (b) on the other hand depicts interference at the level of meaning. The English "break the law" phrase is directly translated into 
Czech. Nevertheless, Czech does not have this collocation and requires a different word that could be translated into English as "disrupt".

a) Už jsem míchal to?

(Have I mixed it?)

Už jsem to míchal?

b) Rozbiju zákon.

(I will break the law.)

Poruším zákon.

\subsubsection{Aliens - single units}

Lexicon is generally believed to be most vulnerable as to language attrition and the empirical research has also paid most attention to its research (Schmid, 2011). In example (c) singular was used, as can be seen from the form of the adjective. In the target-like structure, however, plural is used. Example (e) represents a mix of interference from English and insertion of English word. The correct Czech phrase uses a different preposition - "u" (at, near), not "v" (in, at).

c) Kompresor dělá různý sound.

(Compressor makes various sound.)

Kompresor dělá různé zvuky.

d) Jak se to ř́ká, Sabra to je refugee camp, Palestinian.

(How do you say it, Sabra, it is a refugee camp, Palestinian.)

Jak se to ř́ká, Sabra, to je uprchlický tábor, palestinský.

e) Oni byli v power.

(They were in power.)

Oni byli u moci.

f) Byla konference, která ukončila válku v Libanonu, civil war.

(There was a conference which ended the war in Lebanon, civil war.)

Byla konference, která ukončila válku v Libanonu, občanskou válku.

\subsubsection{Bigger aliens - multiword stretches}

Examples of intra-sentential code-switching are presented below. In this subgroup more linguistic material coming from English is embedded in the Czech structures. As in the case of word order, in example (h) the influence of Arabic might be evident because the word for a town area or a quarter has a masculine gender (Hayy) as opposed to Czech, where it is a feminine noun. 
g) May be now deset procent křestanů.

(May be now ten percent of Christians.)

Možná ted' deset procent křest'anů.

h) To je unofficial čtvrt' budovaný against the law.

(It is an unofficial area built against the law.)

To je neoficiální čtvrt' budovaná protizákonně.

i) Pracoval jsem na reception centre pro počasí, pro transmission počasí mezi letišti of the world, aby oznámili, kolik je stupňů, jaký je windspeed for example ve Francii, v Praze.

(I worked at the reception centre for weather, for transmission of weather among the airports of the world so that they can say how many degrees there are, what the windspeed is for example in France, in Prague.)

Pracoval jsem v přijímacím centru pro počasí, pro přenos počasí mezi letišti světa, aby oznámili, kolik je stupňů, jaká je rychlost větru, například ve Francii, v Praze.

\subsubsection{Mix}

Very rarely both second languages interacted and switched at various levels. In the example (j) the Czech word "kostel" (church) is embedded in an English matrix structure accompanied by the definite article and getting the English plural marker "-s". Similarly, a neologism was created by combining the English adjective "destroyed" with the Czech adjectival suffix in the example (k) below. Both examples could be considered as examples of intra-word switching or, according to Schmid (2011, p. 57) as a grammatical borrowing. The sentence is grammatically wrong as the verb is using neuter ending "-o" instead of the correct female ending "-a" and masculine ending "-ý" on the adjective while the word "mosque" has female gender in Czech - "mešita" - thus the adjective should end in "-á".

j) He entered the mosque, he entered the kostels, churches.

(He entered the mosque, he entered the churches, churches.)

k) Když mosque bylo destroyený.

(When the mosque was destroyed.)

\section{Discussion}

From the examples in this paper it is apparent that English has influence on Czech at two levels. The first one - interference - leads to non-target-like usage of Czech. We have seen two examples of this type of influence - word-order and semantic deviation. The second type of influence is more salient as transparent units from English are explicitly used in Czech structures. Sometimes only small grammatical elements are present, sometimes single units or bigger chunks are 
used. Example (e) shows a rare mix of both types of influences - insertion of an English word plus interference at the syntactic level as the wrong preposition is used, evidently transferred from English. English items have been fully integrated into the Czech structures, and vice versa, Czech word "kostel" was inserted into an English structure, getting English plural ending and definite article. We might consider this type of data as a proof of the role of English as a backup language in case some Czech elements are inaccessible. However, the question is whether for example borrowed lexical items were a part of the vocabulary at all. As the access to the level of the language is not possible (only through self-evaluation) it is difficult to determine what words were part of the lexicon and fully acquired and which words were not. Lexical borrowings should thus never be interpreted as a straightforward evidence of language attrition (Schmid, 2011, p. 26).

When looking at the code-switched elements in our case study in a greater detail, they are connected to specific topics - mainly politics (moc - power, občanská válka - civil war, uprchlický tabor - refugee camp), religion (mešita - mosque) and work (přijímací centrum - reception centre, přenos - transmission a rychlost větru - windspeed). Most expected and logical is the influence of English in the area of topics related to work. In this case, however, it is difficult to distinguish whether it is the result of language attrition or natural dominance and cross-linguistic influence of the language of work. As mentioned above, we cannot check, whether the vocabulary was acquired also in Czech and to what extent it was used in Czech in the work area. As to the word "mosque", the reasons for not accessing the Czech equivalent "mešita" may be, besides attrition, also cultural, and once again the question is whether it was acquired in Czech at all.

Generally, the occurrences of the code-switched materials were rare, thus in fact challenging our original idea of English as a backup due to attrition. It is quite possible that English serves as a backup not due to attrition but due to the fact that the units were never acquired in Czech thus leaving the data as an evidence of language maintenance rather than attrition. Attrition is clearly defined as an individual phenomenon intimately linked to social aspects of language use (Köpke, 2007, p. 9). When reflecting on the reasons from language attrition or the lack of it we need to search within the area of extralinguistic factors, such as personal background factors - age of acquisition, age of onset of attrition, length of residence, attitude and motivation among others. Schmid (2011, p. 95) says that it is uvdots the opportunity to use a language, the willingness to do so and the attitudes and emotions which a speaker has towards this language are interacting variables in the language attrition process .... Some of these generally assumed factors, i.e. old age and time, should be, however, treated with extreme caution (p. 79). In our case it seems that the emotional coding of the language represents the strongest factor for making the language alive. Czech was not only acquired in an instructional context but it was also implicitly "experienced" and "lived", simply 
connected to our subject's life, it is cognitively embodied (Pavlenko, 2012) and thus more resistant to forgetting and attrition by creating a different representation of the linguistic structures in memory (Schmid, Mehotcheva, 2012).

While negative or traumatic emotions may serve as the reason to reject a language (for details see Schmid (2002) and her research on Holocaust survivors) strong positive emotions can keep it alive. In the context of teaching this would strongly support us to teach languages in naturalistic contexts for example via immersion rather than through instruction only. If we want our teaching to be efficient and long-lasting, we should encourage our students in getting involved with naturalistic input. Last but not least, students should be motivated. Where there is motivation there is a higher chance of attaining a higher level or proficiency. Where there is a motivation there is a stronger will to keep the language alive. If the learner's willingness to communicate derives more from himself and his genuine need or desire to transmit a message rather than the syllabus and artificial situations in the classroom, the less probable will language attrition be (Schmid, Mehotcheva, 2012).

\section{Conclusion}

In this paper I tried to show how English can serve as a backup in a specific multilingual situation. Items from English became an integral part of Czech structures enabling the speaker to speak fluently and continue the conversation. It is evident that time alone is not enough for a language to attrite and that use it or lose it approach does not necessarily work (Schmid, 2019, 2011; Schmid, Mehotcheva, 2012). "Since the multilingual's linguistic subsystems do not exist in isolation but are connected at multiple levels (e.g. Paradis, 2007; Schmid \& Köpke, 2017), any kind of use of any language means that all other languages will receive a certain amount of stimulation ... The interconnectedness of the language subsystems means that the activity and accessibility of each subsystem exist in a complex pattern of processes related to memory retrieval, suppression and interaction." (Schmid, 2019). Furthermore, according to Schmid and Mehotcheva (2012) we need to definitely stress the scientific benefits from attrition research as it contributes to better understanding of human memory and the mechanisms that are connected to language acquisition and processing (p. 7). Last but not least not only in research but in general and mainly in our classes we need to perceive each linguistic situation as unique (Yates and Terraschke, 2013) and in our interpretation and understanding it we should always try to leave enough space for individual and highly variable approach to language learners and users (Pavlenko, 2005). 
I would like to thank Eva Složilová for having the chance to discuss the data with her as to the possible influence of Arabic. And I would like to thank my parents for keeping their languages alive.

\section{Bibliography}

AuER, P. (Ed.) (2002). Code-Switching in Conversation. Language, Interaction and Identity. Routledge, London. URL: https://epdf.pub/ code-switching-in-conversation-language-interaction-and-identity.html

Code-Mixing and Code-Switching. In Concise Oxford Companion to the English Language. URL: https:// www.encyclopedia.com/humanities/encyclopedias-almanacs-transcripts-and-maps/ code-mixing-and-code-switching

DEWAELE, J. (1998). Lexical Inventions: French Interlanguage as L2 versus L3. Applied linguistics, 19 (4), 471-490.

KöPKE, B. (2007). Language attrition at the crossroads of brain, mind, and society. In KöPKE, B. ET AL. (Eds.), Language Attrition. Theoretical perspectives (9-37). New York: John Benjamins.

MANFREDI, S. ET AL. (2015). Language contact, borrowing and code-switching. In METTOUCHI, A. ET AL. (Eds.), Corpus-based Studies of lesser-described Languages: the CorpAfroAs Corpus of spoken AfroAsiatic languages (pp. 283-308). New York: John Benjamins.

Myers-Scotton, C. (1992). Comparing Code-Switching and Borrowing. Journal of Multilingual and Multicultural Development, 13(1), 19-39.

Murphy, S. (2003). Second Language Transfer During Third Language Acquisition. Teachers College, Columbia University Working Papers in TESOL \& Applied Linguistics, 3(1).

Nebeská, I. (2017). Bilingvismus. In Karlík, P., Nekula, M., Pleskalová, J. (Eds.), CzechEncy - Nový encyklopedický slovník češtiny. URL: https://www.czechency.org/slovnik/BILINGVISMUS

Nekula, M. (2017). Jazykový kontakt. In Karlík, P., Nekula, M., Pleskalová, J. (Eds.), CzechEncy - Nový encyklopedický slovník češtiny. URL: https://www.czechency.org/slovnik/JAZYKOVÝ KONTAKT

Nekula, M. (2017). Výpůjčka. In Karlík, P., Nekula, M., Pleskalová, J. (Eds.), CzechEncy - Nový encyklopedický slovník češtiny. URL: https://www.czechency.org/slovnik/VÝPŮJČKA

PARADIS, M. (2007). L1 attrition features predicted by a neurolinguistic theory of bilingualism. In KöPKE, B. ET AL. (Eds.), Language Attrition. Theoretical perspectives (pp. 121-134). New York: John Benjamins.

Pavlenko, A. (2005). Emotions and Multilingualism. Cambridge: CUP.

PAVlenko, A. (2004). L2 influence and L1 attrition in adult bilingualism. In Schmid, M., KöPKE, B. ET AL. (Eds.), First Language Attrition: Interdisciplinary Perspectives on Methodological Issues (pp. 47-59). Amsterdam: John Benjamins.

SElinker, L., \& BAUMgartner-Cohen, B. (1995). Multiple language acquisition: “Damn it, why can't I keep these two languages apart?" In BEnSousSAN, I. ET AL. (Eds.), Multilingualism and language learning: 8, 2. Language, culture and curriculum (pp. 115-123).

Schmid, M. S. (2019). The impact of frequency of use and length of residence on L1 attrition. In ScHMID, M. S., \& KöPKE, B. (Eds.), The Oxford Handbook of Language Attrition. Oxford: OUP.

Schmid, M. (2011). Language Attrition. Cambridge: CUP.

Schmid, M. (2002). First Language Attrition, Use and Maintenance: The Case of German Jews in Anglophone Countries. Amsterdam: John Benjamins. 
Schmid, M. S., \& Meнотснеva, T. (2012). Foreign language attrition. Dutch Journal of Applied Linguistics 1(1), 102-124.

YATES, L., \& TERRASCHKE, A. (2013). Love, Language and Little Ones: Successes and Stresses for Mothers Raising Bilingual Children in Exogamous Relationships. In SchwARTz, M., \& VerSCHIK, A. (Eds.), Successful Family Language Policy. Parents, Children and Educators in Interaction (pp. 105-126). Dordrecht: Springer.

\section{Author}

Linda Doleží, Ph.D., Masaryk University Language Centre, e-mail: dolezi@med.muni.cz The author is a language teacher and teacher trainer. She works as an Assistant Professor at Masaryk University Language Centre and at the Department of Czech Language of Faculty of Arts. Author is a former methodologist of the State Integration Programme and she specializes in language support for childrenforeigners, in particular refugees. She focuses on teaching methodology, language acquisition and psychoand neurolinguistics in multilingual contexts. Her current interests include language attrition phenomena and the role of emotions and trauma in language acquisition and attrition. 